\title{
Inovation Heat Treatment of Coining Dies - Analysis of the Microstructural Parametres Tool Steels
}

Daniela Kalincová ${ }^{1}$, Miroslava Ťavodová ${ }^{1}$, Rudolf Kaštan ${ }^{2}$

${ }^{1}$ Faculty of Environmental and Manufacturing Technology, Technical University in Zvolen, Študentská 26, 960 53. Slovak republic. E-mail: tavodova@tuzvo.sk, kalincova@tuzvo.sk

${ }^{2}$ Mincovňa Kremnica, State Enterprise. Slovak Republic. E-mail: rudolf.kastan@gmail.com

This paper deals with research of the heat treatment of tool steels Böhler K 455, K605 that are determined for production of tools for minting circulation coins. The aim of the research was to determine the impact of introduction of innovative heat treatment on the structural parameters and lifetime of coining dies. Experimental part presents the results of purity evaluation at semi-products with use of EDX analyse of the non-metallic inclusions, also microstructure evaluation, measurement of the size austenite grain after application of innovative heat treatment also. After ending of analysis and evaluation of lifetime coining dies, new parameters of heat treatment for using at the production were proposed.

Keywords: tool steel, innovation, thermal treatment, microstructure, size of austenitic grain, lifetime, coining dies

\section{References}

[1] KAŠTAN, R. (2016). Výskum zvyšovania spol'ahlivosti a životnosti nástrojov na razenie mincí tepelným spracovaním: PhD thesis,. Zvolen: Technická univerzita vo Zvolene. Fakulta environmentálnej a výrobnej techniky. 2016. 139 s. 0 príloh.

[2] ŤAVODOVÁ, M., KALINCOVÁ, D., KAŠTAN, K. (2016). The Research of Options for the Innovation Heat Treatment of the Tools for Coinage in Order to Increase their Lifetime, In. Manufacturing Technology. Vol. 16, No. 1, ISSN 1213-248

[3] ZÁBAVNÍK, V., BURŠÁK, M.( 2009). Materiál, tepelné spracovanie, kontrola kvality. Košice: Emilena, 2009, 291 s. ISBN 978-80-553-0139-6

[4] KŘÍŽ, A. (2003). Vady tepelného zpracování rychlořezných ocelí. Mezinárodní konference Vakuové tepelné zpracování a tepelné zpracování nástroju․ Trenčín, 2003

[5] BÖHLER, K455 Cold work tool steel [online]. 2016, [cit.2016-08-20]. Internet: http://www.bohleredelstahl.com/media/productdb/downloads/K455DE.pdf

[6] BÖHLER, K605 Cold work tool steel [online]. 2016, [cit.2016-08-20]. Internet: http://www.bohler.at/deutsch/files/downloads/K605DE.pdf

[7] VÍŠEK J, Nikel, V. Hodnocení růstu zrna uhlíkových a nízkolegovaných nástrojových ocelí v závislosti na přítomnosti AlN [online]. 2016, [cit.2016-08-20]. Internet: stc.fs.cvut.cz/pdf/VisekJaroslav-338820.pdf

[8] DIN 50 602. (1985). Mikroskopische Prüfung von Edelstählen auf nichtmetallische Einschlüsse mit Bildreihen

[9] KALINCOVÁ D. (2013). Výskum faktorov vplývajúcich na kvalitu a životnost’ nástrojov pre razenie mincí. $H a$ bilitačná práca, Fakulta výrobních technologií a managementu Univerzity Jana Evangelisty Purkyně v Ústí nad Labem, $154 \mathrm{~s}$.

[10] PELAGIĆ, Z., NÁGEL', M., ŽMINDÁK, M., RIECKY, D. (2015) Wear Simulation Modeling by Using the Finite Element Method In. Manufacturing Technology. Vol. 15, No. 2, ISSN 1213-248

[11] BELAN, J., HURTAlOVÁ, L., VAŠKO, A., TILlOVÁ, E. (2014) Metallography Evaluation of IN 718 after Applied Heat Treatment In. Manufacturing Technology. Vol. 14, No. 3, ISSN 1213-248

[12] STN EN ISO 643: 2013 Steels - Micrographic determination of the apparent grain size 